\title{
Research on the Main Obstacles and Copying Strategies of Property Tax Reform from the Perspective of Functional Orientation
}

\author{
Weishuang $\mathrm{Xu}^{1, \mathrm{a} \text {, * }}$ \\ ${ }^{1}$ College of Economics and Management, Qilu Normal University, Jinan, Shandong, China \\ axwsjn@163.com
}

\section{Keywords: Property Tax; Function Orientation; Main Obstacles; Coping Strategies}

\begin{abstract}
Restraining the asset bubble" has become the main goal of the country's macroeconomic regulation and control. One of the most important targets for this is the real estate bubble. Restraining the real estate bubble can only rely on fiscal policy, and it is one of the effective fiscal policies to levy property tax on residents' non-operating houses. However, the property tax reforms pilot in Shanghai and Chongqing in 2011 did not achieve the desired results. Therefore, the trial promotion of China's property tax has been relatively slow. In 2018, China's real estate tax legislation and property tax reform has entered a substantive stage. Based on this, on the basis of analyzing the function orientation and main obstacles of property tax in our country, this paper puts forward the coping strategies to smoothly promote the reform of property tax from the aspects of clear thinking, clarity property right, perfect evaluation mechanism and tax preference. In order to speed up the process of the reform of real estate tax legislation and property tax in our country.
\end{abstract}

\section{Introduction}

"Restraining the asset bubble" has become the main goal of the country's macroeconomic regulation and control. One of the most important targets for this is the real estate bubble. Restraining the real estate bubble can only rely on fiscal policy, and it is one of the effective fiscal policies to levy property tax on residents' non-operating housing. Property tax has the advantages of tax base not easy to flow, stable income, fair and reasonable etc.. It is a kind of tax that all countries have levied. Under the traditional property tax system, residents' non-operating houses aren't levied on the property tax. While the property tax accompanying the real estate tax legislation refers to levy taxation on residents' non-operating houses. The property tax reform piloted in Shanghai and Chongqing in 2011 was given great expectations. People hope to adjust the social gap between the rich and the poor, curb house prices and promote the rational allocation of housing resources through reform. However, the property tax reforms pilot in Shanghai and Chongqing in 2011 did not achieve the desired results. Therefore, the trial promotion of China's property tax has been relatively slow. In 2018, China's real estate tax legislation and property tax reform has entered a substantive stage. Xiao Jie, the Minister of Finance, said that the legislation and implementation of the real estate tax should be promoted in accordance with the principle of "legislation first, full authorization and step-by-step advancement". Through which a perfect modern real estate tax system should be gradually set up. Based on this, on the basis of analyzing the function orientation and main obstacles of property tax in our country, this paper puts forward the coping strategies to smoothly promote the reform of property tax. In order to speed up the process of the reform of real estate tax legislation and property tax in our country.

\section{The Function Orientation of Property Tax}

Function orientation of property tax in the general sense. Huang Fengyu and Liu Chang (2016) [1] thought that it required two important prerequisites to smoothly promote the reform of property tax :one is the accurate functional orientation, and the other is to clarify the practical constraints in the process of reform. Generally speaking, there are three views on the functional orientation of property tax. 
Expand tax source and improve financial revenue. The basic function of taxation is to raise financial revenue, and property tax is no exception. The function of property tax in improving revenue is mainly reflected in the following aspects: (1) Increase local financial revenue. Property tax has obvious regional income characteristics in increasing local financial revenue. The Levy of property tax can make local government obtain new and sustained income sources. (2) Replace land transfer fees to improve local fiscal revenue structure. Local governments have become more dependent on land finance after the reform of "business tax changed to value-added tax". Because the property has the same immobility as the land, so it will get rid of the dependence of local governments on land finance after the Levy of property tax. Yu Chengjin and Yu Ying (2016) [2] thought that the levy of property tax on urban residents could improve the welfare of residents, stimulate economic growth, improve the level of employment and suppress the housing price than land transfer fees.

Adjust the real estate market. At present, the biggest problem of China's real estate market is the prevalence of speculative behavior and the real estate bubble is more serious. Property tax can regulate the real estate market from the following aspects: (1) Increase the risk of speculation and the cost of holding real estate. Property tax can provide an effective constraint for the housing market in a relatively long period. When housing prices rise too quickly, the risk of speculation and the cost of holding property can be suppressed to a certain extent. (2) It will help investors form a stable and reasonable expectation. The introduction of property tax is a long-term mechanism. Therefore, it does not mean that property tax will reduce the real estate price immediately and the real estate market will return to rationality immediately. Instead, it will show that people will adjust their expectations, the economic behavior will be more rational and the market will be more stable.

Adjust the distribution of social income. Property tax can regulate the distribution of social income from the attributes of direct tax and capital tax. (1) Property tax is a direct tax. Its tax return is clear and the tax burden is not easy to transfer. Therefore, property tax can become a new force of regulating income distribution. (2) Property tax is a capital tax and its tax burden is progressive. Property tax regulates the income of residents' assets. The skyrocketing of asset prices represented by real estate are the main reasons for the widening income gap in recent years. Therefore, the gap between the rich and the poor brought by asset income must be regulated by property tax.

The function orientation of property tax reform in China. Although property tax in any country has above three functions in theory. But the main function orientation of property tax is also different due to the difference in political system, financial system, economic structure, social environment and so on. Property tax is the most important income source of local government in the Commonwealth countries. Property tax is an important tool for Japan and South Korea to regulate the real estate market during real estate price boom (Deng Juqiu, Xu Wei, Gong Dezhao, 2016) [3]. The difference in function orientation of property tax will inevitably lead to the differences in the implementation measures and mean and the differences in implementation effect.

Property tax has limited ability to raise local fiscal revenue. Although property tax has been levied very early in China, but property tax has limited capacity to raise local fiscal revenue. According to the information provided by National Data Network (2018)[4], although the total income from property tax in China has gradually increased from 2007 to 2016, but the proportion of property tax as a percentage of local fiscal revenue and tax revenue is $2-4 \%$. On the contrary, the land transfer fees accounted for 40-50\% of local fiscal revenue in 2007-2016. This shows that property tax does not play a very good role in local finance revenue. The reason is as following: (1) China's real estate holding link tax collection is vacant and pays excessive attention to the real estate tax in transaction link. (2) China's taxation for non-operating houses is vacant.

Property tax does not play an effective role in regulating the real estate market in China. In 2011, China began to levy property in Shanghai and Chongqing. Its purpose is to adjust the social gap between the rich and the poor, guide individuals to rational housing consumption and promote the healthy development of the real estate market. However, due to the unreasonable design of various tax elements, the property tax pilot has not achieved the expected goals. Wang Yanni (2017) 
[5] believes that the property tax pilot in Shanghai and Chongqing has not played a significant role in regulating housing prices.

Regulating the distribution of social income is the main function of China's property tax. The primary function of property tax is to regulate the distribution of social income has been recognized by most scholars. Liu Chang (2017) [6] believes that the function of China's property tax should be oriented in adjusting income distribution. Through taxation on houses holding links, we can achieve the goal of reducing excessive accumulation wealth and narrowing the gap between the rich and the poor. Liu Jindong and Ding Zhaoyang (2017) [7] believe that property tax can't be a local subject tax in terms of adequacy or rationality. Regulating social income distribution is its only core function. Especially in 2018, Shi Yaobin, the Deputy Minister of Finance made it clear that property tax is first the adjustment tax, and then the income tax (Li Yujia, 2018) [8].

\section{The Main Obstacles of Property Tax Reform under the Function of Regulating Social Income Distribution}

Unclear property rights result in difficulties in determining the scope of property tax levy. Since the main function of property tax is to regulate the distribution of social income, then theoretically all property should be included in the scope of taxation. If not, the taxpayers will try to avoid tax and that will cause greater injustice. However, there are still many special types of housing with ambiguous property rights in China, such as small-property housing, welfare housing, affordable housing, limited-price housing and joint-property housing. If all of these properties are included in the scope of taxation, it may increase the burden of residents. However, if some property is not included in the scope of taxation, it may lead to unfair taxation and will not achieve the function of regulating income distribution.

The imperfection of evaluation mechanism leads to the difficulty of determining the tax base of property tax. The internationally-accepted basis for property tax is assessment value, but the property tax levied in Shanghai and Chongqing in 2011 did not adopt assessment value. The main reason is that China's real estate assessment mechanism is not perfect, reflected in the following: (1) The evaluation mechanism for tax base of property tax is lack. This mainly manifested in the fact that China has not yet issued a national unified framework for assessing tax base of property tax. (2) There is no clear tax base assessment agency for property tax. In our country, the local tax bureau is generally responsible for the tax base assessment of property tax. However, the local tax bureaus are not fully competent for the evaluation of tax base of property value due to the restriction of various factors. (3) It has not formed a professional assessment team for property tax assessment. The imperfection of evaluation mechanism will result in the lack of reliable tax base and unfair taxation.

Other related supporting policies are not perfect. In addition to property rights and evaluation mechanism, the levy of property tax must also be supported by other supporting policies. If not the effect of property tax will be greatly discounted. But in general, China's related supporting mechanisms are not perfect: (1) The lack of unified registration system of real estate that leads to the problem of insufficient and incomplete of property information. Although the state put forward unified registration of real estate in the form of law in 2007, the progress of unified registration is slow due to the serious conflict of interests in the departments, the contradiction of redistribution of power and the legal problems. (2) The imperfection of credit system has made it more difficult to collect property taxes. The imperfections of the credit system result in the collection of property tax more difficult. The cost of failing to pay property tax is relatively low. (3) The imperfect preferential tax policies have led to the serious problem of double taxation. The implementation of property tax has been seriously resisted by the stakeholders.

\section{Coping Strategies to Speed up the Reform Progress of Property Tax in China}

Clear the main idea of property tax reform. Property tax reform is a far-reaching and extensive system project. There are inextricable correlations between various tax systems and taxes. Therefore, 
how to make the property tax reform have a close system of consistency and effectively create a reasonable real estate consumer market should become the primary task of property tax reform. We should follow the tax reform policy of "simple tax system, wide tax base, low tax rate and strict collection of management", in line with the basic direction of real estate tax reform of "positive tax, clear rent and less fee". All property should be included in the tax scope of property tax and not only the incremental property after the reform.

Clarify property rights and speed up nationwide networking of property rights information of real estate. The clarity of property rights is an important basis for promoting property tax reform. The government will not have the right to levy property tax on taxpayers if property rights are ambiguous. Therefore, in view of the problems of ambiguity property rights in China's real estate market, the relevant departments should actively promote the registration of real estate property and realize the real-name registration in real estate. On this basis, we should speed up the nationwide networking and open inquiry of real estate property rights information so as to create conditions for the full levy of real estate tax. Fortunately, the "Real Estate Registration Provisional Regulations" has come into effect in March 2015 and the unified registration of real estate has finally entered a substantive stage.

Establish a perfect real estate evaluation mechanism. Improve the real estate evaluation mechanism and earnestly implement the real estate evaluation value as the tax base of property tax. Specifically: (1) Explore the mechanism of real estate tax base assessment in line with China's national conditions and introduce a nationwide framework for a unified property tax base assessment mechanism. (2) Clear the setting of property tax base assessment agency. In order to avoid the contradiction between the rights allocation of various departments of our government, a new institution or department can be set up which is specially responsible for the tax base assessment of property tax. (3) Select and cultivate a professional tax base assessment team. The influence of talent quality on assessment results is more crucial because the tax base assessment of property tax is more complicated. We can learn the mature experience of foreign countries, formulate the training and management system of real estate assessment professionals and improve the "admissions" and " accredited" mechanism of assessment personnel. (4) Design effective follow-up dispute settlement mechanism for evaluation, coordinate and reduce disputes in the property evaluation process.

Fully consider residents' tax bearing capacity and improve tax preferential policies. Liu Jindong and Ding Zhaoyang (2017) believe that there is a certain proportion of low income families unable to pay taxes regardless of tax rate and deduction areas how to design. Therefore, preferential tax policies must be considered in the formulation of property tax related systems and supporting measures. The formulation of preferential tax policies can be considered from the following aspects: (1) The preferential tax policies in view of property tax itself, such as tax base reduction, special deductions, tax deductions, low tax rates and special group preferences. (2) Other preferential tax policies related to property taxes. For example, reduce the tax burden of other taxes related with property tax, carry out reform of personal income tax etc..

\section{Reference}

[1] Huang Fengyu, Liu Chang.the Policy Dilemma and Outlet of Property Tax Reform [J]. Tax and Economic Research, 2016(09).

[2] Yu Chengjin, Yu Ying. The Effect of Property Tax on the Replacement of Land Transfer Fees--Based on Computable General Equilibrium Simulation Analysis [J]. Sub National Fiscal Research, 2016(02)

[3] Deng Juqiu, Xu Jing, Gong Dezhao. International Comparison and Enlightenment of Property Tax Function Orientation [J]. Sub National Fiscal Research, 2016(05).

[4] http://data.stats.gov.cn/easyquery.htm?cn=C01 
[5] Wang Yanni. The Discussion about the Current Difficulty of Real Estate Tax Reform in China--Based on the Analysis of Taxation Collection and Administration Practice [D]. Jinan: Shandong University, 2017.

[6] Liu Chang. International Experience and Enlightenment of Property Tax Function Orientation and Tax Base Orientation [J]. Financial Perspectives Journal, 2017(10).

[7] Liu Jindong, Ding Zhaoyang. Measurement of the Affordability of Property Tax for Urban Families --On the Feasibility of Property Tax to be the Main Local Tax [J]. Collected Essays on Finance and Economics, 2017(06)

[8] Li Yujia. Property tax finally made it clear [N]. Securities Times, 2018-03-12 (A03). 